\title{
Liquidation of ammonia clouds using a mobile turbine rescue and firefighting system
}

\author{
Małgorzata Majder-Łopatka ${ }^{1, *}$, and Tomasz Węsierski ${ }^{1}$ \\ ${ }^{1}$ Szkoła Główna Służby Pożarniczej (Main School of Fire Service), ul. Juliusza Słowackiego 52/5, \\ 01-629 Warszawa Poland
}

\begin{abstract}
Given its extensive industrial use and chemical properties ammonia is a source of serious hazards in the event of its uncontrolled releases. The mobile turbine rescue and fire-fighting system (MTSRG), equipped with a special $\mathrm{SO}^{3-} \mathrm{W}$ aircraft turbine with $10 \mathrm{kN}$ power and water efficiency of $6 \mathrm{~m}^{3} / \mathrm{min}$, can be used to liquidate spatial gas clouds by diluting them with combustion gases and sorption on the surface of the produced water microdroplets. The publication presents calculations related to the effectiveness of the system during the uncontrolled release of ammonia from a pressure vessel. To estimate the performance of this system, use was made of water stream droplet size research, kinetics studies of ammonia sorption, $\mathrm{SO}^{3-} \mathrm{W}$ turbine parameters at a safe working distance, as well as results of ammonia concentration simulation using the ALOHA program. A combined simulation carried out for a rupture of DN100 pipe supplying liquid ammonia to spherical tank with a diameter of $16.6 \mathrm{~m}$ and filled in $70 \%$ showed that it is theoretically possible to reduce the ammonia concentration by as much as $95.75 \%$ while the vehicle is operating at a working distance of 60 meters from the rupture. The exhaust gases together with the entrained air contribute mainly to the reduction of the concentration of ammonia through the mechanism of dilution $(91.6 \%)$. Water mist generated by the vehicle is theoretically responsible for the reduction of ammonia concentration by only $4.15 \%$.
\end{abstract}

\section{Introduction}

Given its wide range of applications, ammonia may cause diverse chemical hazards [1-4]. The production of ammonia only in Poland in anhydrous form and in an aqueous solution (calculated as pure NH3) amounted in 2016 to 2623 and 96.4 thousand tones, respectively [5]. Consequently, the elimination of spatial contamination of ammonia has often been the object of scientific research [6-9]. The greatest hazards occur in case of uncontrolled release is ammonia in liquefied form. Due to the pressure in tanks containing liquid ammonia and the fact that ammonia in such a state is at a temperature much higher than the boiling point, its release quickly generates a significant cloud with corrosive and toxic properties. The spatial liquidation of ammonia clouds would be possible by using highly efficient technologies that provide significant amounts of water per unit of time in the form of a fine

* Corresponding author: mmajder@sgsp.edu.pl 
spray. One of such technologies is the turbine rescue system that ejects water in the form of a fine spray generated by breaking of solid water jet by the exhaust stream of the turbine. Such a vehicle called MTSRG (Mobile turbine rescue and firefighting system) with a $\mathrm{SO}^{3-} \mathrm{W}$ turbine of $10 \mathrm{kN}$ thrust is presented on Figure 1. The technology enables the dissipation of 6 $\mathrm{m}^{3}$ of water per minute, whereby the obtained water fine spray has an average drop diameter of $51 \square \mathrm{m}$ and covers an area of $800 \mathrm{~m}^{2}$. Such a droplet size generated over a huge surface should ideally absorb vapours of dangerous substances that are soluble in water. An additional advantage is the huge amount of exhaust gases diluting the cloud and the ability of operating the system from a considerable distance.

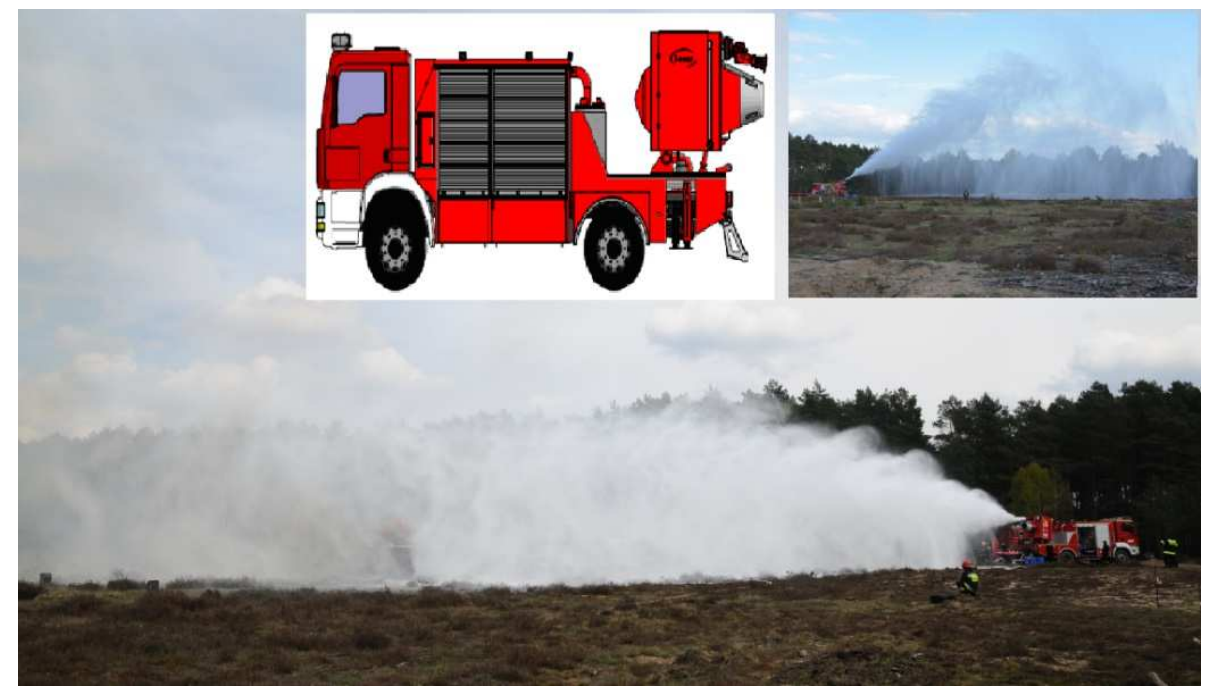

Fig. 1. Mobile turbine rescue and firefighting system (MTSRG) equipped with SO3-W turbine having a $10 \mathrm{kN}$ thrust

The contamination elimination method generally used by rescue units consisted in the first place in limiting the leakage and further spreading by applying water curtains. However, it did not allow spatial liquidation of chemical clouds. This was made possible by using high efficiency water monitors. However, the depth of penetration and the sorption efficiency is considerably smaller than the solution presented in this article.

\section{Research methodology}

In analyses of diverse possibilities of applying turbine extinguishing systems in the liquidation of ammonia chemical clouds, the following analytical methods, technical parameters and test results were used:

- estimation of the effects of uncontrolled outflow of ammonia in the computer program ALOHA 5.4.4,

- kinetic studies of reduction of ammonia concentration as a function of time through water curtains,

- $\quad$ testing of average droplet diameters using a Drop Spectrum Analyzer IPS (AWK),

- technical parameters of the $\mathrm{SO}_{3}$.

An analysis was carried out for leakage of a ball-shaped pressure vessel with a diameter of $16.6 \mathrm{~m}$ and liquid ammonia filled in $70 \%$. The release scenario assumes that a DN100 supply pipe becomes broken up as a result of a catastrophic event at the level of the tank bottom. According to assumptions the ambient temperature was $10^{\circ} \mathrm{C}$, at average cloudiness. 
The atmospheric stability class was defined as $\mathrm{D}$. The storage temperature of liquefied ammonia in a spherical tank with incomplete cooling was set at $10^{\circ} \mathrm{C}$ (maximum permissible).

Studies related to kinetics of reducing ammonia concentration were performed at a test stand for kinetics of the effectiveness of water curtains as shown in Figure 2. The stand has a test chamber measuring $1.2 \times 1.2 \times 1.2$ meters, a boom for mounting the spray nozzle, an ammonia supply system to the test chamber consisting of a heating bowl and a flask, as well as a supply line characterised by adequate mechanical strength and chemical resistance. In the course of the research, ammonia was obtained by desorption of $\mathrm{NH}_{3}$ from $25 \%$ ammonia water. The stand was also equipped with a water supply system having a tank capacity of $0.25 \mathrm{~m}^{3}$ enabling the setting and regulation of liquid flow parameters - pressure and efficiency, a drop tank and a gas analyzer (Photoionization detector MX 6 made by Industrial Scientific) to record the concentration of ammonia in the chamber as a function of time.

For needs of the tests used was made of three types of spray nozzles made by BETE Deutschland GmbH with the markings: TF 6 (spiral nozzle), CW-50 F (nozzle with full spraying cone), P48 (fog nozzle). For working pressures, they provided drops with mean surface diameters of $600 \mathrm{~mm}, 235 \mathrm{~mm}$ and $185 \mathrm{~mm}$, respectively. The Drop Spectrum Analyzer was used to study average droplet diameters and pulverization spectra IPS (AWK) made by Zakład Elektronicznej Aparatury Pomiarowej K $\mu \mathrm{K}$ in Warsaw. The AWK analyzer makes it possible to determine the average diameter of droplets and the distribution of droplet diameters within the range from 0.5 to $3000 \mu \mathrm{m}$. The analyzer consists of a measuring probe, a stand, power cords, a signal converter and a PC (Fig. 3).

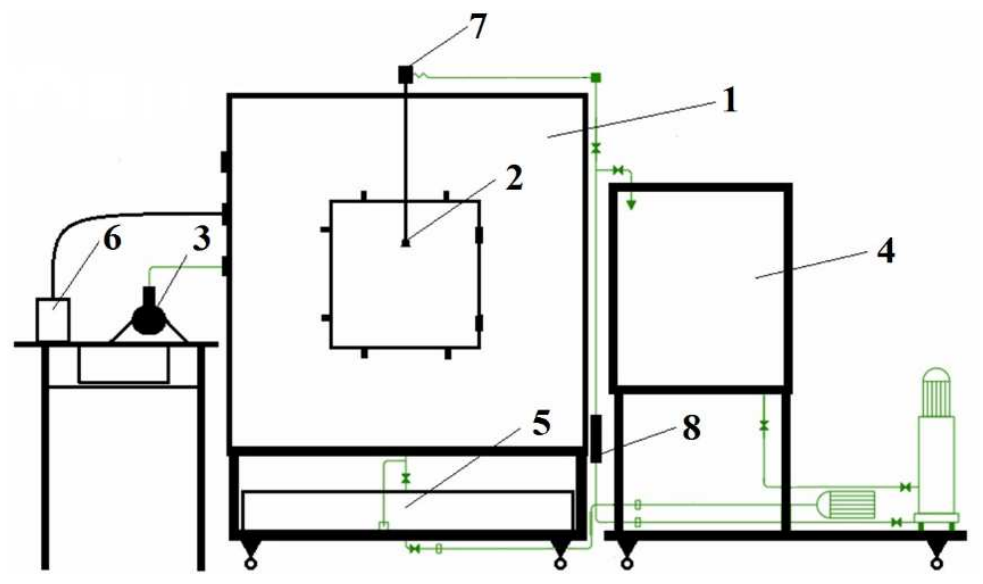

Fig. 2. Diagram of testing arrangement; 1 - research cell, 2 - spray nozzle, 3 - bowl heater with the flask, 4 - water tank, 5 - dumping tank, 6 - gas detector (PID), 7 - pressure sensor, 8 - flow sensor

The technical parameters of the SO3-W turbines were assumed as parameters of the turbine system taking into account a safe working distance of $60 \mathrm{~m}$ for rescuers with full protection. At the start position, the turbine air expense is $13.8 \mathrm{~m}^{3} / \mathrm{s}$ [10]. Assuming a significant excess of air in relation to fuel and an increase in the temperature of combustion gases from $20^{\circ} \mathrm{C}$ to $650^{\circ} \mathrm{C}$, the volume of exhaust gases escaping per unit of time is $46.7 \mathrm{~m}^{3} / \mathrm{s}$ [11]. This is a volume of gases similar to that of Turbolöscher II for which the volume of generated exhaust gases at the outlet of the turbine is $50 \mathrm{~m}^{3} / \mathrm{s}$. Considering these parameters, the estimated volume of exhaust gases together with the air sucked in by the high-velocity exhaust gases at a working distance will be about $1850 \mathrm{~m}^{3} / \mathrm{s}$. The water capacity of the system was assumed at $6 \mathrm{~m}^{3} / \mathrm{min}$. The direction of the projection of the turbine water stream, which is consistent with the wind direction, was assumed as the direction perpendicular to the axis of the direction of the cloud's propagation. 


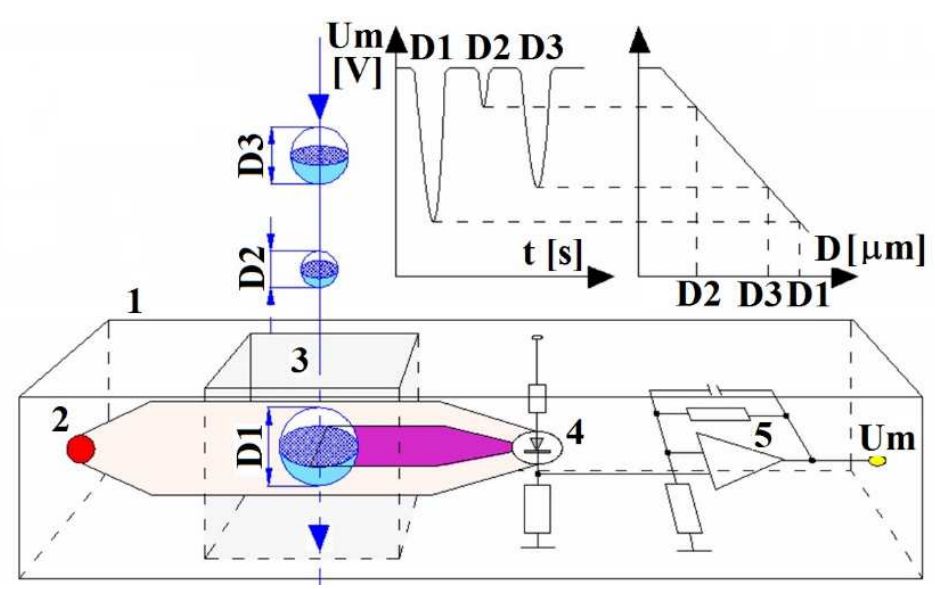

Fig. 3. Drops Spectrum Analyzer IPS: 1 - probe 2 - transmitter, 3 - measuring space , 4 -receiver, 5 - electronic arrangement, D1, D2, D3 - adequate size of droplets

\section{Results and discussion}

The simulation performed in the program ALOHA 5.4.4 indicates that for pressure vessel break described in the test methodology an outflow may be anticipated at a maximum intensity of $7690 \mathrm{~kg} / \mathrm{min}$. During the first hour, the intensity of the outflow will only slightly decrease. The maximum concentration of ammonia at a distance of $\mathrm{X}$ from the place of outflow oriented along the propagation of the cloud is shown on Figure 4. The time for the reaction for rescue teams is very short. For example, at a distance of $2 \mathrm{~km}$, the maximum concentration value outside objects equalling to $1330 \mathrm{ppm}$ would be reached practically after only 6 minutes (insert figure 4). This means that it would only be possible to use efficiently the turbine technology if the leakage occurred as a result of a secondary accident on the site of the plant where other activities with the use of a turbine vehicle would have been going on.

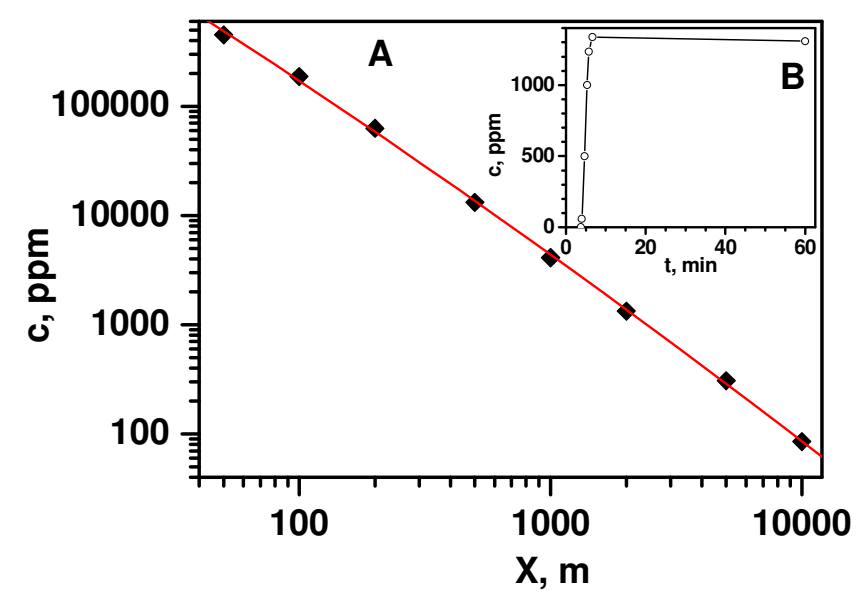

Fig. 4. A) Maximal concentration of ammonia at a distance $X$ from the point of release for assumed simulation conditions B) Outdoor concentration of ammonia for assumed conditions $2 \mathrm{~km}$ from the point of outflow. 
At the maximum flow intensity determined with the use of the program as being $7690 \mathrm{~kg} / \mathrm{min}$ (assuming some cooling of steaming ammonia) approximately $170 \mathrm{~m}^{3}$ of ammonia vapour could be generated in a second. Hence, effective application of the same exhaust gas stream with an intensity of $1850 \mathrm{~m}^{3} / \mathrm{s}$ could theoretically reduce the concentration of ammonia to $8.4 \%$ of the initial value, if such a variant would be feasible taking into account security reasons. Consequently, the concentration reduction would be as high as $91.6 \%$. It should be borne in mind that ammonia is a combustible substance and at a working distance of 60 meters one could expect ammonia concentrations of up to $360000 \mathrm{ppm}$ when only the direction of the wind changes. As a result there would be a great risk of LEL exceeding $15 \%$ $(150000 \mathrm{ppm})$ at the presence of a very large ignition source such as a turbine, despite being supplied with water. This would be feasible at the aforementioned change of wind direction at the moment of starting the turbine and being aware that water is fed from the top parallel to the exhaust gas stream. However, it should be clearly emphasized that during the turbine operation, a large volume of exhaust gases and their high velocity would not allow such a high concentration of ammonia in the vicinity of the turbine.

The reduction of ammonia concentration resulting from the action of dispersed water streams was estimated for the analyzed case by means of kinetic studies of the change in ammonia concentration in the chamber as a function of time.

Changing the concentration of ammonia in the test chamber at the time of supplying water streams through spray nozzles is similar to the exponential decay which can be described by the pseudo-first order kinetic equation given below:

$$
-\frac{d[C]}{d t}=k_{p}[C]
$$

where:

C - ammonia concentration In chamber [ppm],

$k_{p} \quad-\quad$ apparent rate constant of the sorption process $\left[\mathrm{s}^{-1}\right]$.

The apparent absorption rate constant kp depends on parameters of the liquid flow and the degree of water spray fragmentation. The course of changes in ammonia concentration as a function of time in the test chamber for the tested nozzles was shown in Figure 5. The determined values of the apparent sorption rate constant for the tested nozzles at a water efficiency of $130 \mathrm{dm}^{3} / \mathrm{h}$ are shown in Table 1 .

Table 1. The apparent velocity of ammonia absorption $\mathrm{kp}$ in the kinetic region of maximal sorption

\begin{tabular}{|c|c|c|c|c|c|}
\hline \multirow{2}{*}{$\begin{array}{c}\text { Type of } \\
\text { nozzle }\end{array}$} & Model & Pressure & Efficiency & $\begin{array}{c}\text { Mean surface droplet } \\
\text { diameter }\end{array}$ & $\mathrm{k}_{\mathrm{p}}$ \\
\cline { 3 - 6 } & $\mathrm{P}[\mathrm{bar}]$ & $\mathrm{V}\left[\mathrm{dm}^{3} / \mathrm{h}\right]$ & $\mathrm{Ds}[\mu \mathrm{m}]$ & {$\left[\mathrm{s}^{-1}\right]$} \\
\hline $\begin{array}{c}\text { Spiral } \\
\text { nozzle }\end{array}$ & TF 6 & 0,5 & 130 & 600 & 0.0087 \\
\hline $\begin{array}{c}\text { Nozzle } \\
\text { with full } \\
\text { sprinkling } \\
\text { cone }\end{array}$ & CW-50 F & 4 & 130 & 235 & 0.0142 \\
\hline $\begin{array}{c}\text { Fog } \\
\text { nozzle }\end{array}$ & P48 & 6,5 & 130 & 185 & 0.0164 \\
\hline
\end{tabular}

An analysis of the relation between the reciprocal of the apparent ammonia sorption rate constant and the mean surface diameter of droplets allows achieving the equation $1 / \mathrm{kp}=0.127 \mathrm{D}_{\mathrm{s}}+38.92$ with a correlation of $\mathrm{R} 2=0.997$ (Fig. 6). On this basis, by 
extrapolating we can predict that for droplets $D_{s}=51 \mu \mathrm{m}$ equal to the size of the mean surface diameter of the distributed water streams generated by MTSRG, corresponds to $\mathrm{k}_{\mathrm{p}}=0.022 \mathrm{~s}^{-1}$.

The range of effective operation of MTSRG is an ellipse having an area of approx. $800 \mathrm{~m}^{2}$. With a water effectiveness of $6000 \mathrm{dm}^{3} / \mathrm{min}=100 \mathrm{dm}^{3} / \mathrm{s}$, this gives an average surface spray intensity of $0.125 \mathrm{dm}^{3} / \mathrm{m}^{2} \mathrm{~s}\left(450 \mathrm{dm}^{3} / \mathrm{m}^{2} \mathrm{~h}\right)$. The surface intensity of spraying in the test chamber with base dimensions of $1.2 \times 1.2$ meters and water capacity $130 \mathrm{dm}^{3} / \mathrm{h}$ is $0.025 \mathrm{dm}^{3} / \mathrm{m}^{2} \mathrm{~s}$.
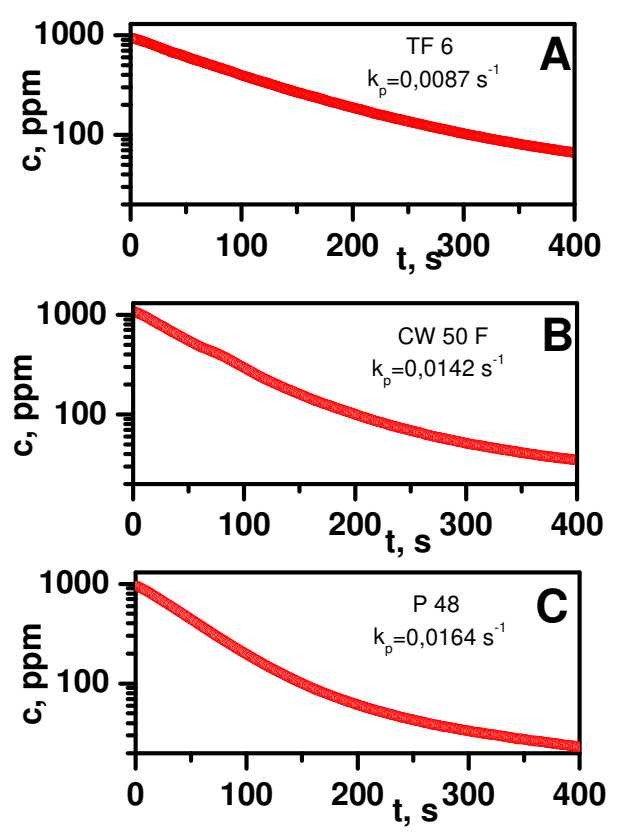

Fig. 5. Ammonia concentration vs time in research chamber for the TF 6, CW50-F and P 48 nozzle. Water efficiency $\mathrm{V}=130 \mathrm{dm} 3 / \mathrm{h}$, water temperature $\mathrm{T}=20^{\circ} \mathrm{C}$.

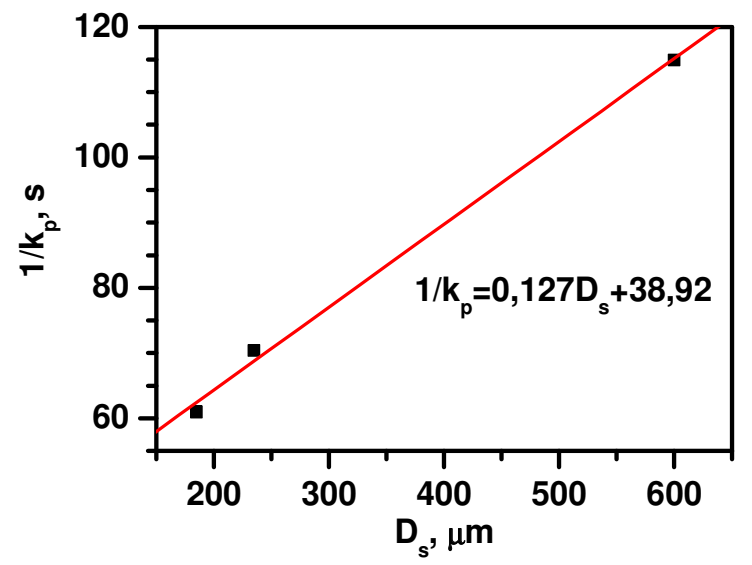

Fig. 6. Dependence of the reciprocal apparent rate constant of adsorption vs. mean surface diameter 
To determine the value of the apparent rate constant of the sorption process $\mathrm{k}_{\mathrm{p}}$ corresponding to the surface intensity of spraying specific for MTSRG, a study was made on the relationship between water efficiency and the value of the constant $\mathrm{k}_{\mathrm{p}}$ (Fig. 7). The measurements were carried out for a full cone CW50-F nozzle. The obtained dependence is expressed by the equation $\mathrm{k}_{\mathrm{p}}=8.78 \times 10^{-5} \mathrm{~V}+0.00287$. Hence the extrapolated $k_{p}$ value corresponding to the intensity of MTSRG spraying is $\mathrm{k}_{\mathrm{p}}=0.04238 \mathrm{~s}^{-1}$.

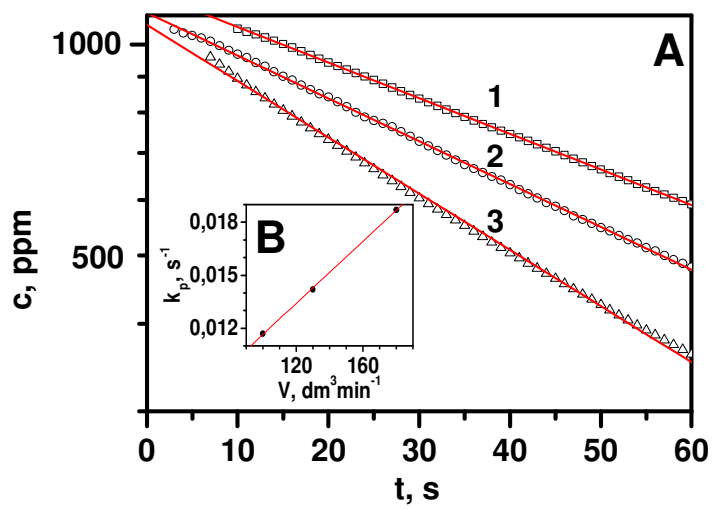

Fig. 7. A) Ammonia concentration vs time in kinetic range for the water efficiency. 1) $100 \mathrm{dm}^{3} / \mathrm{h}$, 2) $\left.130 \mathrm{dm}^{3} / \mathrm{h}, 3\right) 180 \mathrm{dm}^{3} / \mathrm{h} \mathrm{B}$ ) dependence between apparent rate constant of adsorption and water efficiency

Further calculations related to reducing the concentration by applying water currents can be made using the dependence of $\operatorname{lnC}-\ln C_{0}=-\mathrm{kt}$ and based on the presumption that at such a significant emission in the vicinity $f$ the place of release one can expect practically pure ammonia. A time interval of 1 second was assumed for calculations. Hence the maximum degree of absorption by dispersed water spray for continuous ammonia outflow allow absorption in the first second of $4.15 \%$ of the ammonia released within the examined time interval in the space covered by the MTSRG operation.

For the analyzed very unfavourable leakage scenario involving a rupture of a DN100 pipe at the bottom of a 16.6 meter diameter spherical tank filled in $70 \%$, the total concentration reduction through the MTSRG vehicle would therefore be approximately $95.75 \%$ at a working distance of 60 meters. This value could be theoretically even greater considering that the liquid phase that has not managed to evaporate during the release would be partly diluted by the already fallen water which could be in the first phase frozen. However, the amount of ammonia absorbed in this way is difficult to estimate. It should be borne in mind that although one volume of water is theoretically able to absorb 1176 volumes of ammonia gas in normal conditions, the surface of sorption and mixing (not taking into account small short-lived puddles of non-vaporized ammonia) would be very small in relation to the sorption surface of mist droplets.

\section{Conclusion}

The calculations showed that MTSRG furnished with a $\mathrm{SO}_{3}-\mathrm{W}$ turbine having a $10 \mathrm{kN}$ thrust and generating a volume of $1850 \mathrm{~m}^{3} / \mathrm{s}$ of exhaust gas with air sucked into the stream from the environment, can provide an effective means for the liquidation of chemical contamination on a very large scale. Combined simulation carried out in the ALOHA 5.4.4 program of a rupture of a DN100 pipe supplying liquid ammonia to a spherical tank with 
a diameter of $16.6 \mathrm{~m}$ and filled in $70 \%$, along with measurements of the mean surface diameter and measurements of the rate of ammonia sorption by water streams in the test chamber have shown that it is theoretically feasible to reduce the ammonia concentration by as much as $95.75 \%$ while the vehicle is operating at a working distance of 60 meters away from the rupture. The exhaust gases together with the entrained air contribute mainly to the reduction of the concentration of ammonia through the mechanism of dilution. This effect constitutes up to $91.6 \%$ of reduced concentration. Kinetic tests in the test chamber showed, however, that the water mist generated by the vehicle theoretically reduces ammonia concentration by only $4.15 \%$. This indicates that water efficiency is greater than in the case of Turbolöscher II, despite the smaller amount of water, which is related to the smaller diameter of the droplets generated in the exhaust stream of the $\mathrm{SO}^{3-} \mathrm{W}$ engine [6].

The research was carried out as part of the DOB-BIO6 / 06/11/2014 project financed by NCBiR "Mobile turbine rescue and firefighting system"

\section{References}

1. Keim M. E., Introduction to chemical disasters, [in:] Ciottone's Disaster Medicine (Second Edition), Elsevier, (2016)

2. Pritchard J.D., Compendium of chemical hazards ammonia, Health Protection Agency, London, (2011)

3. Amshel C.E., Fealk M.H., Phillips B.J., Caruso D.M., Anhydrous ammonia burns case report and review of the literature, Burns, 26, 5, pp. 493-497, (2000)

4. Wróblewski D., Węsierski T, Retrospektywna analiza uwolnienia się amoniaku w Drzycimiu w kontekście faz przygotowania i reagowania modelu zarządzania kryzysowego, Przem. Chem., 90, pp. 2100-2104, (2011)

5. Rocznik statystyczny przemysłu 2017, Główny Urząd Statystyczny, Warsaw ,(2017)

6. Węsierski T., Majder-Łopatka M., Wąsik W., Likwidacja skażeń przestrzennych amoniaku za pomocą turbinowych pojazdów gaśniczych, Przem. Chem., 96, pp. 10801084, (2017)

7. Hua M., Xiaohui S., Juan Z., Xuhai P., Protective water curtain ammonia absorption efficiency enhancement by inorganic and surfactants additives, Process Safety and Environmental Protection, 116, pp. 737-744, (2018)

8. Hua M., Qi M., Yue T., Pi X., Pan X., Jiang J., Experimental Research on Water Curtain Scavenging Ammonia Dispersion in Confined Space, Procedia Engineering, 211, pp. 256-261, (2018)

9. Xiaohui S., Juan Z., Hua M., Pan X., Experimental research on decontamination effect of water curtain containing compound organic acids on the leakage of ammonia, Process Safety and Environmental Protection, 105, pp. 250-261, (2017)

10. Silnik SO3-W. Opis silnika, Wytwórnia sprzętu kominikacyjnego PZL Rzeszów, First Edition, (1977)

11. Ruchała P, Dziubiński A., Silniki odrzutowe SO 1 i SO3, Polska Technika Lotnicza. Materiały historyczne, 66, 1, pp. 1-8, (2011) 